\title{
STUDI KOMPERATIF MODEL BUMDES DI KABUPATEN BANTAENG
}

\author{
Andi Samsir \\ Dosen Ekonomi Pembangunan Universitas Negeri Makassar \\ Email : syamsir_fe03unm@yahoo.co.id
}

\begin{abstract}
ABSTRAK
Pendapatan masyarakat pesisir yang tergolong masih sangat rendah merupakan fenomena yang masih dapat terlihat di Kabupaten Takalar dan Pangkep. Berdasarkan baseline survey ketahanan pangan yang dilakukan oleh Oxfam bekerjasama dengan Perkumpulan Katalis pada tahun 2015 di dua daerah tersebut menunjukan bahwa hal ini disebabkan oleh rendahnya produktivitas lahan pertanian dan rumput laut serta kurangnya modal usaha yang dapat diakses oleh masyarakat local. Hal tersebut mengindikasikan bahwa desa harus mengambil peran yang besar secara makro ekonomi untuk memecahkan masalah-masalah di pedesaan yang memberikan implikasi secara mikro ekonomi. Dengan demikian, berbagai lembaga ekonomi pedesaan menjadi bagian penting sekaligus dalam rangka mendukung penguatan ekonomi perdesaan. Jenis penelitian ini adalah bersifat kualitatif (deskriptif research) dengan menggunakan data primer dan sekunder yang diperoleh melalui teknik field work research dan library research dengan teknik proporsive and snowball sampling dari lembaga BUMDes yang ada di Kabupaten Bantaeng. Berdasarkan hasil penelitian di lapangan dapat ditarik beberapa kesimpulan diantaranya; pertama, BUMDes yang dikembangkan di Kabupaten Banteng dapat mendorong dan mengembangkan potensi ekonomi desa; kedua, unit usaha yang dikembangkan melalui BUMDes seperti unit usaha simpan pinjam, perdagangan, dan agroindustri dianggap mampu mengatasi permasalahan yang dihadapi oleh masyarakat pesisir Kabupaten Takalar dan Pangkep.
\end{abstract}

Kata Kunci: Model BUMDes, ekonomi pedesaan, pembangunan pedesaan

\section{PENDAHULUAN}

Pendapatan masyarakat pesisir yang tergolong masih sangat rendah merupakan fenomena yang masih dapat terlihat di Kabupaten Takalar dan Pangkep. Berdasarkan baseline survey ketahanan pangan yang dilakukan oleh Oxfam bekerjasama dengan Perkumpulan Katalis pada tahun 2015 di dua daerah tersebut menunjukan bahwa hal ini disebabkan oleh rendahnya produktivitas lahan pertanian dan rumput laut serta kurangnya modal usaha yang dapat diakses oleh masyarakat local. Besarnya biaya produksi yang harus ditanggung oleh petani membuat mereka harus mencari berbagai 
46|Ad'ministrare, Vol. 3 No. 2, 2016

cara untuk tetap bisa menjalankan usaha budidaya rumput laut (Siswan, 2015). Berdasarkan data BPS tahun 20015 rata-rata biaya produksi per hektar sebesar 57,22 persen dari nilai produksi atau sebesar Rp 8,052 juta. Dengan tingkat pendapatan yang rendah dan jadwal tanam yang bergantung pada musim sangat memungkinkan sebagian besar petani menggunakan modal usaha mereka untuk menutupi biaya hidup setiap harinya. Oleh karena itu, modal usaha menjadi masalah yang tak kunjung terselesaikan dalam masyarakat yang secara tidak langsung mempengaruhi terhadap tingkat kemiskinan di daerah pesisir.

Untuk memecahkan masalah lingkaran kemiskinan di daerah pesisir, peran pemerintah khususnya pemerintahan desa sangat dibutuhkan sebagaimana yang diamanatkan Undang-Undang Nomor 23 Tahun 2014 tentang Perubahan atas UndangUndang Nomor 32 Tahun 2004 tentang Pemerintahan Daerah, Dapat dikatakan, otonomi desa merupakan suatu gagasan besar dalam memberikan kesempatan yang sama kepada masyarakat untuk tumbuh dan berkembang mengikuti perubahan-perubahan baik di bidang ekonomi, politik, dan sosial budaya. Hal tersebut mengindikasikan bahwa desa harus mengambil peran yang besar secara makro ekonomi untuk memecahkan masalahmasalah di pedesaan yang memberikan implikasi secara mikro ekonomi. Dengan demikian, berbagai lembaga ekonomi pedesaan menjadi bagian penting sekaligus dalam rangka mendukung penguatan ekonomi perdesaan. Oleh karenanya, diperlukan upaya sistematis untuk mendorong kelembagaan ini agar mampu mengelola aset ekonomi strategis sekaligus mengembangkan jaringan ekonomi dalam rangka meningkatkan daya saing ekonomi di pedesaan. Dalam konteks demikian, BUMDes merupakan bentuk konsolidasi atau penguatan terhadap lembaga-lembaga ekonomi desa yang harus dikembangkan, sekaligus sebagai instrumen pendayagunaan ekonomi lokal dengan berbagai ragam jenis potensi.

Badan Usaha Milik Desa (BUMDes) sebagaimana amanat UU No. 6 Tahun 2014 tentang tentang Desa dimaksudkan untuk mendayagunakan segala potensi ekonomi, kelembagaan perekonomian, serta potensi sumber daya alam dan sumber daya manusia dalam rangka meningkatkan kesejahtraan masyarakat desa. Sebagai lembaga usaha ekonomi desa, pembentukan dan pengelolaan BUMDes dimaksudkan sebagai instrument seluruh kegiatan ekonomi mandiri desa (peningkatan Pendapatan Asli Desa/PADes dan kesejahteraan masyarakat desa), baik yang berkembang menurut adat istiadat/budaya setempat (kearifan lokal), maupun kegiatan perekonomian yang diserahkan untuk dikelola oleh masyarakat desa.

Adapun yang menjadi tujuan dalam penelitian ini adalah; pertama, untuk mengetahui model pengelolaan BUMDes yang efektif melalui studi komperatif yang dilakukan di Kabupaten Bantaeng; dan kedua, untuk merancang model BUMDes yang efektif dalam mengatasi permasalahan yang dihadapi masyarakat pesisir di Kabupaten Takalar dan Pangkep. 


\section{KAJIAN TEORI}

Pembangunan daerah pedesaan merupakan discourses yang masuk dalam kajian ekonomi pembangunan. Daerah pedesaan merupakan representatif kehidupan sosial-ekonomi di negaranegara berkembang. Sebab, sebagian besar penduduk di negara berkembang bermukim di pedesaan dan mayoritas penduduknya bergantung pada sektor pertanian dan berada di bawah garis kemiskinan. Salah satu ciri penting dari penduduk pedesaan adalah masalah kepemilikan tanah. Tahan masih merupakan modal utama dari kesejahtraan dan kekuatan politik di wilayah pedesaan. Di sini, untuk mengklasifikasi penduduk desa menurut akses terhadap tanah atau keterlibatan dalam pertanian dapat dilihat dari tingkat keterlibatan rumah tangga tersebut dalam aktivitas lain dan mengamati struktur pendapatan dari sumber-sumber yang lebih luas. Beberapa penulis menggunakan istilah "household survival strategies" sebagai cara penduduk desa mengatasi persoalan-persoalan yang muncul (Michel P. Todaro, 2006).

Dalam prespektif pembangunan, Boeke yang pernah melakukan penelitian di Indonesia khususnya pulau Jawa menemukan bahwa perekonomian terbagi dalam sektor tradisional dan modern yang saling tidak berhubungan. Dalam rangka mengatasi ketidakseimbangan akibat perekonomian dualistic tersebut, menurut Boeke, sektor tradisional perlu dirangsang melalui insentif ekonomi dan peningkatan teknologi produksi meskipun hasilnya tak akan segera tampak. Sebaliknya Geertz menyatakan upaya perbaikan apa pun tidak akan berhasil dilakukan. Menurut Scott persoalan yang berlaku pada masyarakat pedesaan adalah rasionalitas social yang lebih mementingkan kebersamaan ketimbang persaingan. Prinsip moral lebih dominan daripada rasionalitas ekonomi sehingga pendekatan ekonomi akan sulit bekerja pada masyarakat desa. Penetrasi dari luar, baik menyangkut aspek kelembagaan maupun teknologi, malahan akan menimbulkan resitensi. Ketidakmampuan menangkap kultur dan nilai-nilai masyarakat desa inilah yang membuat banyak kebijakan pembangunan pedesaan gagal diterapkan di lapangan (Yustika, 2013).

Ide dualisme ekonomi yang diinisiasikan oleh Boeke tersebut pada akhirnya, diakui atau tidak, menjadi diskursus penting dalam proses pembangunan pedesaan di negara-negara berkembang. Seperti yang telah disarikan oleh Ellis dan Biggs (Yustika, 2013), model dualisme ekonomi menjadi isu strategis pembangunan pedesaan di negara-negara berkembang pada akhir tahun 1950-an. Pada fase pertama ini, tujuan pembangunan pedesaan diarahkan dari semula pembangunan komunitas ke penekanan pertumbuhan usaha tani kecil. Kedua, pertumbuhan usaha tani kecil dilanjutkan kepada upaya pembangunan pedesaan yang terintegerasi di antaranya melalui kebijakan transfer teknologi, mekanisasi dan penyuluhan pertanian. Ketiga, pergeseran pembangunan pedesaan yang dipandu negara menuju liberalisasi pasar melalui kebijakan penyesuaian struktural dan pasar. Keempat, pembangunan pedesaan diarahkan untuk penguatan pendekatan proses, partisipasi, pemberdayaan, dan pelaku. Kelima, pentingnya penghidupan yang berkesinambungan sebagai sebuah kerangka kerja yang terintegrasi dalam pembangunan pedesaan, di antaranya lewat penguatan kredit mikro, jaringan pengamanan 
48|Ad'ministrare, Vol. 3 No. 2, 2016

pedesaan, dan peran perempuan dalam pembangunan. Keenam, menempatkan pembangunan pedesaan sebagai strategi untuk mengurangi kemiksinan.

Jadi, dari penjelasan tersebut, salah satu persoalan paling rumit di wilayah pedesaan adalah penyediaan modal. Bahkan, keterbatasan akses terhadap modal diindentifikasi sebagai salah satu faktor penyebab kemiskinan. Keterbatasan modal menyebabkan sirkulasi kegiatan ekonomi tidak berjalan. Sebaliknya, tanpa ada perputaran aktivitas ekonomi proses akumulasi kapital juga tidak bisa terjadi. Berbekal situasi yang seperti itu, para perumus kebijakan pembangunan pedesaan akhirnya meluncurkan program kredit mikro, sebagai instrument pengembangan kelembagaan sektor finansial di pedesaan.

Pada umumnya lembaga keuangan di pedesaan bisa dibedakan dalam tiga jenis: pertama, lembaga keuangan formal; kedua, lembaga keuangan semi-formal; ketiga, lembaga keuangan informal. Di suatu negara, lembaga keuangan formal biasanya secara opersional diatur dalam undang-undang perbankan dan disupervisi oleh bank sentral. Lembaga keuangan tersebut bisa bank pemerintah maupun swasta. Sementara itu, bank semi-formal adalah perbankan yang tidak diatur dalam UU, tetapi disupervisi dan diregulasi oleh agen pemerintah selain bank sentral. Terakhir, lembaga informal beroperasi di luar regulasi dan supervise lembaga pemerintah. Lembaga ini berisi kegiatan-kegiatan yang benar-benar di luar kelembagaan keuangan resmi, yang sering kali tidak dicatat. Sungguh pun begitu, tidak berarti sektor keuangan informal merupakan kegiatan ilagal. Lembaga keuangan ini tetap legal, hanya saja tidak diregulasi (Soyibo, 1997). Lembaga keuangan informal ini bukan sekedar meyediakan uang cash untuk keperluan transaksi, tetapi kadang-kadang juga memberikan bantuan dalam bentuk barang. Dengan karakter yang fleksibel, biasanya lembaga keuangan informal ini memiliki daya tahan yang kuat untuk hidup wilayah di pedesaan (Yustika, 2013).

\section{METODE PENELITIAN}

Jenis penelitian ini adalah bersifat kualitatif (deskriptif research) dengan menggunakan data primer dan sekunder yang diperoleh melalui teknik field work research dan library research dengan teknik proporsive and snowball sampling dari lembaga BUMDes yang ada di Kabupaten Bantaeng.

\section{HASIL DAN PEMBAHASAN}

BUMDes Ganting yang sekarang berkantor di jalan cengkeh tepatnya dibelakang kantor Desa Labbo merupakan suatu lembaga ekonomi milik desa Labbo yang dirintis melalui musyawarah desa pada tanggal 31 Desember 2008 dan mendapat dukungan dari pemerintah Kabupaten Bantaeng bekerjasama dengan ACCESS-Phase II sejak tahun 2009 sampai saat ini. Lembaga ini bebentuk usaha bersama (UB) yang sudah memilik badan hukum berupa akta notaris sejak tahun 2009. Tujuan pendirian lembaga tersebut diantaranya pertama, Mendorong berkembangnya kegiatan perekonomian masyarakat desa; kedua, meningkatkan kreatifitas dan peluang usaha ekonomi produkstif anggota (berwirausaha) masyarakat desa yang berpenghasilan rendah; ketiga, meningkatkan pendapatan asli desa; keempat, meningkatkan 
pengelolaan potensi desa sesuai dengan kebutuhan masyarakat. Untuk merealisasikan tujuan tersebut, BUMDes Ganting mengelola beberapa jenis usaha berupa pengelolaan air bersih, jasa angkutan dan pengelolaan hutan desa.

Alasan memilih unit usaha tersebut, pertama, kondisi desa yang berada di daerah pegunungan dengan ketinggian 1.200 sampai dengan 2000 meter dpl dengan luasi wilayah $13,81 \mathrm{~km}^{2}$ menjadikan Desa Labbo memiliki potensi lahan yang sangat produktif diantaranya perkebunan dan hutan desa. Dengan luas lahan pertanian 16.296 Ha, masyarakat desa menanam berbagai jenis tanaman jangka panjang seperti cengkeh, kakao, dan berbagai macam buahbuahan. pada saat panen, masyarakat desa menghadapi kendala pemasaran hasil bumi mereka. Oleh karena itu, dengan adanya mobil pick up bantuan pemerintah Kabupaten Bantaeng yang digunakan untuk operasional usaha BUMDes termasuk melayani jasa pengangkutan hasil bumi masyarakat sangatlah membantu dalam pemasaran hasil bumi masyarakat tersebut. Dari unit usaha tersebut pendapatan BUMDes bisa mencapai 350 ribu sampai dengan 750 ribu rupiah perbulan. Masyarakat desa juga mengelola hutan desa dengan luas $504 \mathrm{Ha}$.

Kedua, keberadaan hutan desa menjadi anugrah yang besar bagi masyarakat di Desa Labbo dimana BUMDes Ganting adalah pemegang Hak Kelola Hutan (HPHD). Saat ini ada 119 keluarga yang tersebar di Desa Labbo, dimana Dusun Kampala dan Bonto Tappalang memanfaatkan hutan desa dengan menanam kopi dan memungut madu hutan. Di samping itu, hutan desa menjadi ekosistem yang baik bagi lebah hutan. Untuk memaksimalkan pemanfaatan hasil hutan tersebut, masyarakat membentuk kelompok peternak lebah madu yang beranggotakan 19 orang dengan 190 peti. Sejauh ini lembaga BUMDes masih berperan sebatas membantu kelompok tersebut dalam pemasaran hasil hutan mereka. Ketiga, Untuk memenuhi kebutuhan air bersih masyarakat desa, Sumber mata air dari hutan desa tersebut dialiri melalui pipa melayani 428 rumah tangga yang dikelola oleh BUMDes. dengan biaya yang relatif lebih murah dibandingkan dengan tarif yang dikenakan oleh PDAM yaitu sebesar 500 rupiah untuk biaya beban dan 250 rupiah untuk biaya pemakaian/kubik. Oleh karena itu, dari unit usaha ini BUMDes memiliki penerimaan sebesar 530 ribu rupiah per bulan.

Untuk mendukung pelaksanaan usaha tersebut, modal usaha BUMDes Ganting berasal dari pertama, pemerintah Kabupaten Bantaeng yaitu modal usaha sebesar 100 juta rupiah dan sebuah mobil pick up. Bantuan dana pemerintah tersebut merupakan hibah sedangkan untuk mobil pick up, pengelola BUMDes harus menyetor kepada pemerintah daerah dalam hal ini dinas perhubungan sebesar 150 ribu rupiah setiap bulannya. Kedua, bantuan dari dirjen PMD pusat sebesar 160 juta rupiah. Dana ini merupakan hibah yang diperuntukan pada kegiatan pengembangan desa sehingga dalam penyalurannya sesuai dengan standar operasional prosedur (SOP) dari Dirjen PMD Pusat pemerintah desa harus membentuk kelompok teknis kegiatan tersendiri yang terpisah dengan lembaga BUMDes. Untuk mentaktisi hal tersebut, pemerintah desa merekrut pengurus BUMDes Ganting untuk mengisi jabatan teknis tersebut. Tujuan tersebut bertujuan agar dana tersebut dapat disinerjikan kegiatan-kegiatan desa yang dikelola oleh BUMDes Ganting.

Mengacuh pada peraturan menteri desa, pembangunan daerah tertinggal dan transmigrasi nomor 4 tahun 2015 pasal pasal 17 (b) modal BUMDes terdiri atas penyertaan modal desa dan modal masyarakat. Namun penyertaan modal pemerintah Desa Labbo masih nihil meskipun 
pemerintah memberikan suntikan dana sebesar sembilan juta rupiah pada saat pelaksanaan musyawarah desa di awal tahun 2014. Alasan pemerintah desa mengambil tindakan tersebut bertujuan agar kas BUMDes tetap tidak terganggu. Menurut kepala Desa Labbo penyertaan modal yang nihil tersebut yang bersumber dari dana desa disebabkan oleh masih belum adanya perdes yang mengatur hal tersebut. Sementara itu, partisipasi masyarakat dalam bentuk modal pada BUMDes tersebut juga nihil. Tidak ada alasan pasti dari pengelola yang menjelaskan kenapa hal itu tidak dilakukan.

Sementara itu, hal yang berbeda terlihat pada BUMDes Pinang Raya yang memiliki kantor yang sifatnya belum permanen. Para pengurus untuk sementara waktu berkantor di kantor Desa Rappoa Kecamatan Pajukukang jalan poros Bulukumba Makassar dan sebagaian arsip-arsip penting lembaga tersebut berada di rumah salah satu pengurus baru (sekretaris). Seperti halnya dengan BUMDes Ganting lembaga ekonomi desa tersebut dirintis melalui musyawarah desa pada di awal tahun 2009 dan mendapat dukungan dari pemerintah Kabupaten Bantaeng. Lembaga ini bebentuk usaha bersama (UB) yang sudah memilik badan hukum berupa akta notaris sejak tahun 2009. Tujuan pendirian lembaga tersebut dilatarbelakangi dengan adanya program pemerintah Kabupaten Bantaeng yang ditandai dengan dikucurkannya bantuan dana BUMDes sebesar 100 juta rupiah tiap desa pada tahun 2009 menindak lanjuti Surat Keputusan Bupati Bantaeng Nomor 411/510/XII/2008 Tahun 2008 tentang petunjuk tekhnis pemberdayaan Usaha Ekonomi Masyarakat Melalui Badan Usaha Milik Desa (BUMDes). Berdasarkan hal tersebut, pemerintah desa berinisiasi membentuk lembaga BUMDes dengan diawali pelaksanaan rembug desa (musyawarah desa) dengan beberapa agenda diantaranya; pertama, melakukan analsis sosial yang ada di desa, kedua sosialisasi perencanaan dan program kerja yang bertujuan untuk pengembangan ekonomi masyarakat desa.

Berdasarkan hasil analisis tersebut, dengan terbentuknya lembaga BUMDes Pinang Raya yang dipimpin oleh Abdul Salam Bonda sebagai direktur disepakati beberapa unit usaha yaitu; pertama, perdagangan hasil pertanian, kedua, persediaan perlengkapan pesta dan ketiga, pembibitan sapi. Dari besarnya jumlah hibah pemerintah tersebut yang di kelola oleh lembaga, 20 persen digunakan untuk perlengkapan kantor (ATK) dan 30 persen digunakan untuk membeli bibit sapi sebanyak sepuluh ekor dengan nilai 30 juta rupiah. Sementara itu, sisa modal digunakan untuk membeli perlengkapan pesta dan modal usaha perdagangan.

Berbeda halnya dengan potensi yang ada di Desa Labbo, secara geografis letak desa Rappoa yang berada di sepanjang pesisir selat Makassar. Melalui unit usaha perdagangan, pengelola membeli hasil bumi masyarakat yang diperoleh dari budi daya rumput laut. Dengan hanya mengandalkan modal yang bersumber dari hibah pemerintah, kemampuan modal usaha yang masih kalah bersaing dengan pedagang pengumpul lainnya yang ada di desa, unit usaha ini hanya mampu membeli dalam jumlah yang kecil sesuai dengan harga yang ada di masyarakat. Karena tidak memiliki tempat penyimpanan yang memadai, hasil pembelian tersebut harus dijual kembali ke pedangang besar dengan nilai marjin yang sangat kecil. Jumlah yang kecil dan intensitas yang tidak menentu menyebabkan mereka belum coba untuk memasarkan langsung ke industri yang ada di Kota Makassar. Meski sempat macet pada tahun 2013 yang berdampak terhadap perkembangan usaha tersebut, atas inisiasi pemerintah desa berdasarkan hasil musrembang desa yang dilaksanakan awal tahun 2016 dengan kepengurusan BUMDes yang 
Andi Samsir, Studi Komperatif Model Bumdes Di Kabupaten Bantaeng $\mid 51$

baru disepakati program pengadaan toko petani rumput laut yang akan menyediakan segala kebutuhan pertanian diantaranya, tali bentang dan bibit. Untuk mendukung tujuan pendirian lembaga tersebut. Rapat tersebut juga menyepakati pembentukan unit baru yaitu unit simpan pinjam untuk masyarakat kelas ekonomi mengengah bawah. Salah satu peruntukannya adalah sebagai modal usaha bagi petani rumput laut yang memiliki kendala pada modal usaha.

Untuk mendorong tingkat produktivitas pertanian di desa, pemerintah Desa Rappoa melalui BUMDes juga mengalokasikan dana desa sebesar 56 juta rupiah untuk membeli dua unit traktor. Di samping itu juga, melihat adanya nilai ekonomis dari unit usaha ternak sapi yang selama ini dijalankan, dimana dengan modal tiga juta rupiah per ekor setelah dua tahun memiliki nilai pasar sebesar dua juta rupiah, pemerintah kembali akan mengalokasikan dana desa tahun 2017 untuk penambahan jumlah bibit sapi. Untuk mendorong pembangunan ekonomi di desa pemerintah mencoba mesingerjikan RPJMdes 2020 dengan pelaksanaan program yang ada di lembaga BUMDes Pinang Raya. Bantuan dana tersebut merupakan bentuk partisipasi pemerintah desa dalam penyertaan modal usaha yang dialokasikan dari dana desa sesuai dengan peraturan pemerintah nomor 22 tahun 2015.

Dalam pendirian dan pengelolaan lembaga, prinsip-prinsip pendirian dan pengelolaan BUMDes diantaranya; pertama, prinsip kooperatif pada BUMDes Ganting dan Pinang Raya menunjukan adanya hubungan kerja sama yang baik diantara pengurus yang ditandai oleh kemampuan masing-masing direktur lembaga tersebut dalam membangun komunikasi ke setiap lini yang ada di bawahnya meskipun terkadang terjadi perbedaan persepi tentang tugas pokok dan fungsi masing-masing pengurus. Sinergitas visi dan misi antara pemerintah desa dan pengelola BUMDes ternyata sangat mempengaruhi terhadap kinerja lembaga. Hal ini dapat terlihat pada keberhasilan BUMDes Ganting periode 2012-2014 yang go internasional di masa kepimpinan Muhammad Jamil yang dapat bersinergi dengan Subehan yang mejabat sebagai kepala desa pada saat itu. Namun, pada akhir tahun 2013 setelah terpilihnya Sirajuddin sebagai kepala desa yang baru, Muhammad Jamil tidak lagi mencalonkan diri pada periode berikutnya dengan alasan politis. Sehingga sampai saat ini belum terlihat adanya perkembangan yang signifikan yang dilakukan oleh pengurus yang baru bahkan berdasarkan informasi di lapangan mereka belum melakukan kegiatan apa pun. Berbeda halnya yang terjadi pada BUMDes Pinang Raya, visi misi kepada desa (Irwan Darffan) yang tidak mampu diterjemahkan dengan baik oleh pengurus BUMDes pada periode sebelumnya yang dipimpin oleh Abdul Salam Bonda yang dianggap mengelola lembaga seperti mengelola usaha pribadi. Sehingga pada awal tahun 2016 diadakan musyawarah desa dengan menetapkan kepengurusan yang baru, dimana direktur dan bendahara diisi oleh orang yang baru sementara posisi sekretaris masih dijabat oleh orang yang sama.

Kedua, prinsip partisipatif yang ditunjukan dengan keterlibatan setiap unsur yang ada dalam masyarakat dalam musyawarah desa maupun kegiatan usaha BUMDes, seperti kelompok tani, tokoh masyarakat, tokoh perempuan dan tokoh pemuda. Partisipasi masyarakat dalam pengelolaan dan pengembangan potensi desa sangat diharap seperti dalam pemeliharaan instalasi PDAM. Kepala unit usaha tidak mengandalkan seluruhnya kepada karyawan tetapi juga swadaya dari masyarakat sekitar. Mengingat kecilnya biaya beban dan pemakaian yang dipungut oleh BUMDes, jika hanya mengandalkan tenaga kerja upahan pasti akan menyebabkan 
$52 \mid$ Ad'ministrare, Vol. 3 No. 2, 2016

besarnya kerugian yang akan ditanggung oleh unit usaha yang akhirnya akan dikenakan kepada pelanggan.

Ketiga, prinsip keadilan dan kesetaraan gender juga ditunjukan dalam penelolaan BUMDes dimana kepengurusan tidak hanya didominasi oleh kaum laki-laki tetapi juga pelibatan perempuan dianggap penting seperti ibu Hilmi Ahriani sebagai bendahara pada BUMDes Ganting dan Maryani dan Hadriani masing-masing sebagai sekretaris dan bendahara pada BUMDes Pinang Raya. Meskipun dalam AD/ART pasal 8 poin sangat jelas dibahasakan "Pembentukan BUMDes Ganting Desa Labbo dengan sistem musyawarah dengan melibatkan semua unsur dalam masyarakat dengan ketentuan sebagai berikut: a. Perempuan memiliki keterwakilan, b. Wakil masyarakat paling tidak ada unsur masyarakat miskin". Namun, dalam musyawarah desa tingkat partisipasi kaum perempuan masih sangat minim jika dibandingkan dengan kaum laki-laki. Hal tersebut diantaranya disebabkan oleh kesibukan perempuan dalam mengurusi rumah tangga mereka serta tingkat pendidikan yang umumnya tidak tamat SD menyebabkan mereka merasa canggung untuk hadir dalam forum tersebut.

Keempat, prinsip tranparansi dan akuntabilitas yang ditunjukan dalam pengelolaan kegiatan dan keuangan di kedua BUMDes masih sangat terbatas, yang hanya bisa diakses oleh pihak-pihak tertentu khususnya pengurus inti. Seperti yang terjadi pada lembaga lain pada umumnya, kondisi keuangan BUMDes dilaporkan secara langsung pada akhir periode kepengurusan pada setiap tiga tahun dalam musyawarah desa. Untuk laporan pertanggungjawaban tahunan sesuai dengan AD/ART BUMDes Ganting pasal 22 pengurus berkewajiban memberikan laporan pertanggungjawaban kepada kepala desa selaku komisaris dan kepada masyarakat minimal sekali dalam setahun. Oleh karena itu, pengurus membuat laporan tahunan diantaranya laporan keuangan yang disampaikan dalam bentuk tertulis kepada komisaris. Hal yang sama juga dapat terlihat pada prinsip akuntabilitas di kedua BUMDes tersebut. Pertanggungjawaban kegiatan secara teknis maupun administratif masih dilakukan secara periodik dan persuasif tanpa harus diadakan musyawarah BUMDes pertanggungjawaban (sesuai AD/ART BUMDes Ganting pasal 10).

Kelima, sesuai dengan tujuan pendirian BUMDes di kedua desa tersebut, prinsip sustainabel dari unit usaha yang dijalankan menjadi prioritas. Ketersedian sumber daya alam yang sangat potensial sangat mendukung tercapainya prinsip tersebut. Hal ini dapat terlihat pada setiap unit usaha yang dijalankan oleh BUMDes Ganting dalam mengelola hutan desa. Untuk mempertahankan kualitas dan kuantitas air bersih dan ketersediaan lebah madu yang dikelolah BUMDes Ganting lembaga tersebut menerbitkan Surat Keputusan nomor 03/BMDsGT/LB/KTB/II/2010 tentang pengelolaan hutan desa. Tujuan dari peraturan tersebut adalah agar masyarakat dapat mengakses dan memanfaatkan sumber daya hutan tersebut melalui BUMDes secara lestari dan dapat meningkatkan kesejahtraan mereka secara berkelanjutan. 


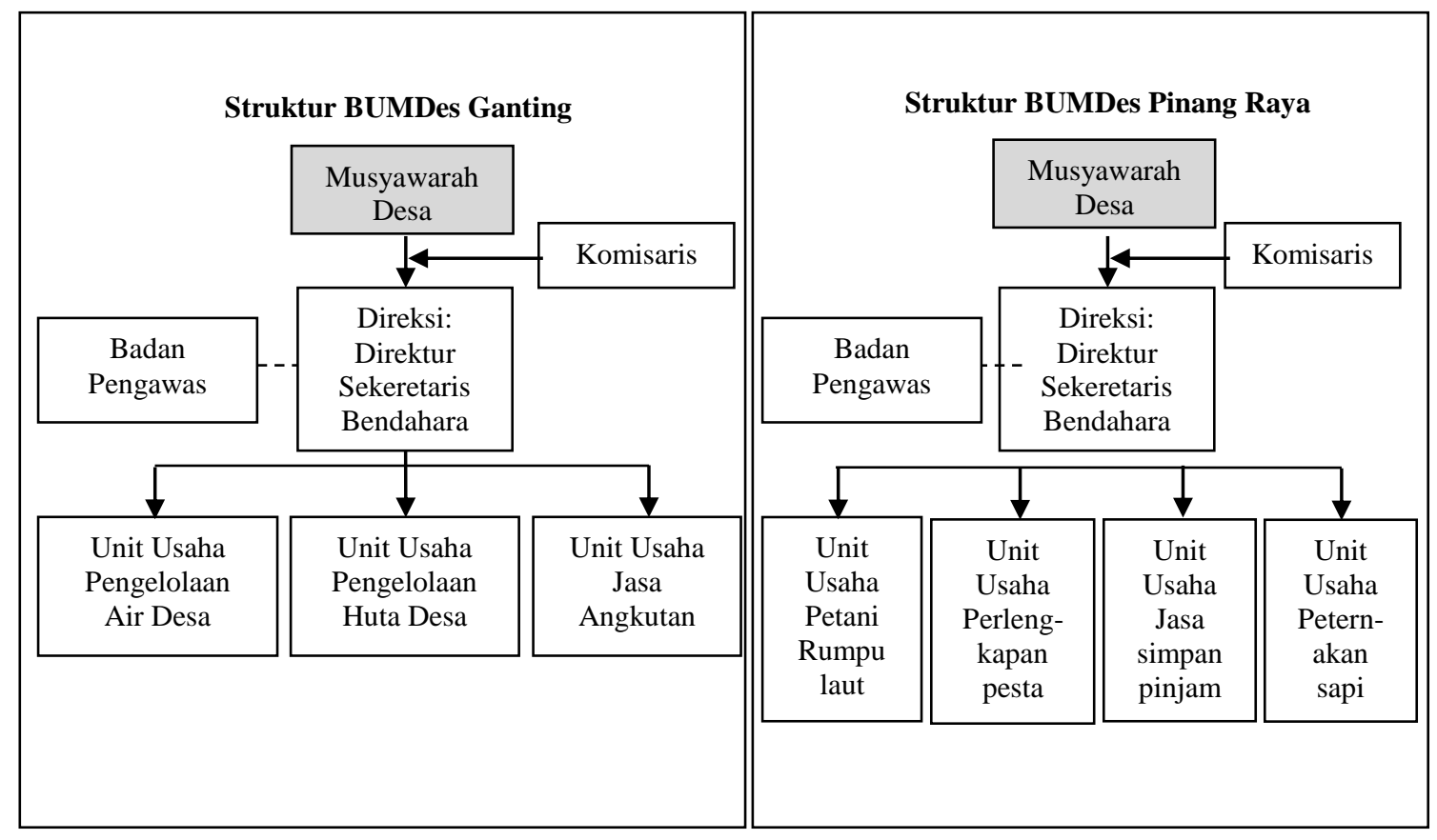

\section{Gambar1. Struktur BUMDes Ganting dan Pinang Raya}

Dalam upaya pengembangan lembaga, BUMDes sebagai lembaga yang berada di era globalisasi yang penuh dengan kompetisi dan sangat dinamis harus sedapat mungkin membuka diri terhadap berbagai pihak, baik pemerintah, swasta mapupun lembaga non-pemerintah. Sebagai lembaga ekonomi desa yang memiliki prestasi, baik ditingkat nasional maupun internasional, BUMDes Ganting telah membangun kerjasama dengan beberapa lembaga dalam dan luar negeri diantaranya; Univesitas Hasanuddin, Rekoptisi (Bangkok), Akses, LSM Balang, dan Forum Komunikasi Kehutan Masyarakat (FKKM).

Untuk dapat mengelola hutan desa sesuai dengan Peraturan Menteri Kehutanan Nomor P.49/Menhut-II/2008 tentang Hutan Desa dan Peraturan Pemerintah Nomor 6 Tahun 2007 tentang Tata Hutan dan Penyusunan Rencana Pengelolaan Hutan, serta Pemanfaatan Hutan sebagaimana telah diubah dengan Peraturan Pemerintah Nomor 3 Tahun 2008 maka atas bantuan Rekoptisi berdasarkan Keputusan Menteri Kehutanan Nomor SK.57/Menhut-II/2010 tentang penetapan kawasan Hutan sebagai Areal kerja Hutan Desa dan Keputusan Gubernur Sulawesi Selatan Nomor 3805/XI/TH 2010 Tentang Pemberian Hak Pengelolaan Hutan Desa di Kawasan Hutan Lindung masyarakat Desa Labbo melalui BUMDes Ganting dapat mengelola hutan desa yang terletak di Kawasan hutan yang terdapat di Desa Labbo sesuai badan planalogi Kehutanan dan hasil Peta paduserasi Provinsi Sulawesi Selatan tahun 1999, seluas 342 ha, berada di $5^{0} 25^{\prime} 20^{\prime \prime}$ - 5023'40" LU dan 119057'30" - 119 $59^{\circ}$ '20" LS Hutan Desa yang dicanangkan di Kabupaten Bantaeng Kecamatan Tompobulu. Untuk dapat mempertahankan 
kelestarian dan keberlangsungan hutan tersebut, melalui fakultas kehutan Universitas Hasanuddin dan FKKM kelompok masyarakat diberi pembinaan dan informasi tentang pengelolaan hutan secara berkelanjutan. Keberadaan dan pengelolaan hutan desa secara terpadu menjadikan BUMDes Ganting dikenal di beberapa negara diantaranya mendapat kunjungan dari pemerintah Timor Leste dan Bangkok serta undangan menjadi nara sumber di Bangkok.

Sementara itu, popularitas BUMDes Pinang Raya belum terlihat seperti yang ada pada lembaga ekonomi desa yang ada di dataran tinggi tersebut. Dengan adanya unit usaha perdagangan dan simpan pinjam mengharuskan lembaga ini menjalin bekerjasama dengan pihak perbankan. Selama ini untuk memudahkan dan demi kelancaran usaha pihak pengelola membangun kerjasama dengan Bank PembangunanDaerah (BPD) Sulawesi Selatan. Tidak ada penjelasan khusus apa alasan pengelola BUMDes memilih kerjasama dengan lembaga keuanga tersebut. Jika dilihat dari jarak lokasi usaha dengan kantor BPD Sulawesi Selatan yang ada di daerah tersebut dapat dengan mudah dijangkau melalui moda transportasi darat, yang kira-kira berjarak $3 \mathrm{~km}$.

Melihat apa yang melatarbelakangi pembentukan BUMDes, dampaknya terhadap masyarakat luas merupakan hal yang mutlak harus ada. Seperti yang tertuang dalam peraturan Desa Labbo Nomor 02 Tahun 2008 pasal 3 tentang tujuan pembentukan BUMDes Ganting yaitu mendorong perkembangan kegiatan ekonomi, jiwa kewirausahaan dan pembentukan unit usaha mikro sektor informal di masyarakat terkhusus bagi mereka yang berpenghasilan rendah. Sejak berdiri pada awal tahun 2009 keberadaan BUMDes Ganting sangat terasa dampaknya di masyarakat, seperti unit usaha air bersih, pengelolaan hutan desa dan jasa angkutan.

Ketersediaan air bersih yang sebelumnya dilakukan secara gotong-royong (swadaya) saat ini mampu dikelola secara profesional. Dengan menggunakan instalasi pipa yang dapat melayani 428 rumah tangga juga dilengkapi dengan meteran agar dapat mengukuran besarnya volume air yang digunakan. Meskipun dikelola secara profesional seperti halnya perusahaan air minum, aspek kepentingan sosial (nirlaba) masih menjadi prioritas utama. Hal ini dapat dilihat dari biaya yang dibebankan kepada masyarakat yaitu sebesar 500 rupiah (beban) dan 250 rupiah per kubik (biaya pemakaian). Selain sebagai sumber air bersih, masyarakat juga dapat memanfaatkan hutan secara terpadu dengan membudidayakan berbagai macam komoditas pertanian seperti kopi dan lebah madu. Agar hutan tetap lestari dan dapat dimanfaatkan secara berkelanjutan peran BUMDes sebagai lembaga desa untuk mengatur tata kelola pemanfaatannya. Bahkan, masyarakat di desa diberikan berbagai pelatihan dan penyuluhan tentang peningkatan kapasitas secara berkelompok. Mereka juga diberikan bantuan bibit pohon agar dapat ditanam di daerah garapan mereka masing-masing. Untuk mengangkut hasil bumi masyarakat desa untuk dipasarkan, keberadaan mobil puck up BUMDes sangat membantu mereka. Bahkan pelayanan jasa angkutan juga menjangkau desa di sekitarnya.

Untuk meningkatkan nilai ekonomis dari hasil budidaya masyarakat seperti kopi tidak langsung di pasarkan tetapi BUMDes Ganting melakukan pembinaan terhadap kaum perempuan di desa yang tergabung dalam "Kelompok Perempuan Mawar" bagaimana mengolah biji kopi menjadi kopi bubuk. Bahkan, melalui kelompok itu juga diajari bagaimana menghasilkan oleholeh khas daerah yang berbahan dasar kopi seperti dodol kopi. Agar produk tersebut dapat menjangkau pasar BUMDes Ganting juga membantu memasarkan produk dari masyarakat 
melalui pameran dan sosialisasi di berbagai even nasional dan daerah serta membangun kerjasama dengan pihak lain diantaranya rekoptisi.

Hal yang sama juga terlihat di desa Rappoa, keberadaan BUMDes Pinang Raya dapat mengerakan perekonomian warga maskipun masih dalam skala kecil. Unit usaha peternakan sapi yang dikelola secara kelembagaan dan perawatannya diserahkan kepada 10 kepala keluarga mampu meningkatkan pendapatan bagi sebagaian masyarakat desa. Karena usaha tersebut jenisnya pembibitan dan sifatnya bergulir maka induk ternak tersebut akan diserahkan ke rumah tangga yang lain agar terjadi pemerataan. Begitu juga halnya dengan keberadaan dua unit traktor dapat membantu meningkatkan produktifitas lahan pertanian masyarakat, dimana sebelumnya mereka harus mendatangkan traktor dari desa tetangga bahkan harus antri agar biasa menggunakan traktor tersebut. Dengan ada dua unit tersebut, pengelolaan lahan pertanian di desa Rappoa dapat dikerjakan lebih cepat dibandingkan sebelumnya.

Meskipun keberadaan toko petani rumput laut belum terealisasi, nanti diharapkan dapat membantu masyarakat khususnya petani rumput laut dalam persediaan perlengkapan dan bahan baku yang dibutuhkan. Besarnya minat masyarakat dalam membudidayakan rumput laut di daerah pesisir selat Makassar akan meningkatkan bebagai macam kebutuhan mereka terutama bibit rumput laut yang memiliki kualitas terbaik. Keterbatasaan modal dan persediaan bibit yang jauh dari lokasi budidaya menjadi masalah yang coba dipecahkan pemerintah desa melalui unit usaha toko petani rumput laut dan simpan pinjam yang dikelola oleh BUMDes tersebut.

\section{Model BUMDes}

Ketergantungan masyarakat yang sangat besar terhadap sector pertanian khususnya rumput laut di daerah pesisir Kabupaten Takalar dan Pangkep menunjukan adanya pengaruh yang besar antara daya beli masyarakat terhadap tingkat produktifitas lahan yang dikelola oleh mereka. Rendahnya daya beli masyarakat khususnya mereka yang mengelola lahan pertanian, mengharuskan mereka untuk menggunakan modal yang seharusnya digunakan untuk usaha budidaya rumput laut, malah digunakan untuk keperluan sehari-hari. Untuk memenuhi kebutuhan modal dalam menjalankan usaha budidaya tersebut dengan harapan penerimaan mereka tetap ada setiap musim panen, meskipun secara ekonomis harus menanggung kerugian, umumnya mereka memilih tengkulak sebagai tempat untuk mendapatkan modal usaha. Ketergantuangan mereka akibat pinjaman tersebut menjadi permasalahan baru yang tak perna terselesaikan buat mereka. Ibarat bola salju yang terus menggelinding yang suatu waktu akan merusak setiap tempat yang dilewatinya mendeskripsikan permasalahan yang dihadapi petani rumput laut yang ada di desa Laikang, Cikoang dan Patopakkang (Syafiuddin Saleh \& Siswan, 2015).

Untuk memecahkan masalah tersebut, peran pemerintah baik daerah maupun desa dianggap sangat penting dalam mendorong perekonomian masyarakat di pedesaan. Upaya yang yang dapat dilakukan berdasarkan hasil studi komparatif (comperative study) yang dilakukan di Kabupaten Bantaeng, dimana keberhasilan pemerintah tersebut mendorong terbentuknya BUMDes di setiap desa menjadi modal tersendiri buat keberhasilan pembangunan di daerah itu. Melihat kondisi dan permasalahan yang ada di daerah pesisir Kabupaten Takalar dan Pangkep, Bentuk usaha BUMDes yang cocok untuk dikembangkan adalah: 
56|Ad'ministrare, Vol. 3 No. 2, 2016

a. Unit usaha simpan pinjam

Kendala modal usaha yang dihadapi oleh petani rumput laut di daerah tersebut dapat diselesaikan melalui unit usaha simpan pinjam. Untuk dapat melakukan peminjaman seluruh mekanisme tersebut diatur dalam ART dan peraturan BUMDes. Penyelengaraan simpan pinjam dimaksud untuk dapat memudahkan masyarakat dalam pelayanan kredit. Sementara itu, sifat dari pinjam ini adalah bersifat pinjaman produktif yaitu, setiap masyarakat yang telah terdaftar sebagai anggota dapat melakukan pinjaman jika memiliki usaha.

Masyarakat yang tidak memiliki usaha tidak diperkenankan untuk mendapatkan pinjaman disebabkan oleh tidak sesuai dengan dasar tujuan pendirian unit usaha itu sendiri. Oleh karena itu, melalui lembaga BUMDes kegiatan pemberdayaan masyarakat secara ekonomi di desa dapat ditingkatkan melalui kegiatan pelatihan yang masuk dalam kegiatan social BUMDes. Kegiatan ini betujuan mendorong dan menciptakan kemampuan kewirausahaan masyarakat di desa sehingga dana yang ada di unit usaha ini dapat bergulir di masyarakat dengan tingkat pengembalian yang tinggi.

b. Unit usaha perdagangan (pertokoan)

Keberadaan unit usaha ini dapat memenuhi kebutuhan masyarakat terhadap perlengkapan yang digunakan dalam budidaya rumput laut melalui keberadaan toko pertanian yang dikelola oleh BUMDes seperti tali bentang, pelampung, dan bibit. Kebutuhan terhadap barang-barang tersebut sebelumnya harus dibeli dengan harga yang relative lebih tinggi yang disediakan oleh pengusaha yang ada di desa. Bahkan, khusus tali bentang sebagaian dari mereka harus ke Kota Makassar untuk mendapatkan jumlah yang lebih besar dengan harga yang dianggap lebih murah dibandingkan harga yang ada di desa dengan selisih harga antara 5 ribu rupiah sampai dengan 10 ribu rupiah per roll (Saleh, 2015). Margin harga yang relatif besar tersebut dapat dipangkas melalui keberadaan unit usaha tersebut, bahkan bisa menjadi laba usaha.

Di samping itu, untuk memotong rantai pemasaran yang begitu panjang dengan marjin harga yang relative besar, unit usaha ini juga dapat melakukan pembelian hasil produksi petani. Besarnya jumlah produksi rumput laut yang ada di daerah tersebut sangat memungkinkan BUMDes langsung dapat menjualnya ke industri yang ada di Kota Makassar. Besarnya margin harga yang ada dalam pemasaran rumput laut, yaitu sebesar 4 sampai 5 ribu rupiah per kilogram, sangat mempengaruhi besarnya potensi pendapat yang hilang dari petani rumput laut yang ada di daerah pesisir kabupaten Takalar dan Pangkep (Saleh, 2015). Dengan pemangkasan rantai pemasaran tersebut secara tidak langsung dapat meningkatkan gairah masyarakat untuk meningkatkan produktifitas usaha mereka. Misalnya, 30 persen dari margin harga itu diberikan kepada produsen dalam bentuk tambahan harga pembelian dan selebihnya menjadi laba usaha yang diperoleh BUMDes. Hal ini tidak hanya mampu meningkatkan pendapatan petani tetapi juga dapat memperkuat kemampuan keuangan lembaga. 
c. Unit usaha agroindustry

Untuk meningkatkan pendapatan rumah tangga petani rumput laut khususnya kaum perempuan perlu adanya industry rumah tangga yang dapat mengolah bahan baku rumput laut menjadi produk yang memiliki nilai tambah (valueadded). Banyaknya produk yang dapat dihasilkan dari bahan baku tersebut seperti snack rumput laut sehingga usaha ini perlu dikembangkan di daerah pesisir. Pelatihan dan penyediaan tehnologi yang bekerjasama dengan pemerintah daerah dan pusat dapat dilakukan untuk mendukung pelaksanaan usaha tersebut.

Dari pelatihan dan teknologi yang tersedia, BUMDes dapat mendesain bentuk usaha yang akan dijalankan, apakah BUMDes melalui unit usaha ini membangun industry yang terpusat di suatu tempat atau hanya mengumpulkan hasil produksi dari home industry yang ada di masyarakat kemudian memasarkannya. Keuntungan dari hanya memasarkan hasil produksi tersebut yaitu hanya membutuhkan modal yang relative kecil. Namun, melihat permasalahan yang ada di masyarakat yang menghadapi kendala modal untuk dapat menjalankan usaha mereka dalam skala kecil (home industry) pada tahap awal BUMDes dapat menjadi pioneer dalam mengembangkan usaha tersebut.

\section{SIMPULAN}

Berdasarkan hasil penelitian di lapangan dengan menggunakan dengan menggunakan beberapa teknik wawancara terstruktur dan pengamatan dapat ditarik beberapa kesimpulan diantaranya; pertama, BUMDes yang dikembangkan di Kabupaten Banteng dapat mendorong dan mengembangkan potensi ekonomi desa; kedua, unit usaha yang dikembangkan melalui BUMDes seperti unit usaha simpan pinjam, perdagangan, dan agroindustri dianggap mampu mengatasi permasalahan yang dihadapi oleh masyarakat pesisir Kabupaten Takalar dan Pangkep.

\section{DAFTAR PUSTAKA}

Yustika, Ahmad Erani 2013, Ekonomi Kelembagaan Paradigma, Teori dan Kebijakan, Erlangga: Jakarta.

Badan Pusat Statistik Sulawesi Selatan, 1/6/2016, Berita resmi statistic No. 74/12/73/Th. II, 23 Desember 2014 (online), http://sulsel.bps.go.id/website/brs_ind/brsInd- 20150430 104723.pdf

Peraturan Menteri Kehutanan Nomor P.49/Menhut-II/2008 tentang Hutan Desa

Peraturan Pemerintah Nomor 6 Tahun 2007 tentang Tata Hutan dan Penyusunan Rencana Pengelolaan Hutan, serta Pemanfaatan Hutan 
58|Ad'ministrare, Vol. 3 No. 2, 2016

Michel P. Todaro, 2006, Pembangunan Ekonomi, edisi kesembilan, Erlangga: Jakarta.

Siswan, 2015, Laporan Survei Ketahanan Pangan Kabupaten Pangkep dan Takalar. Makasar

Saleh, Syafiuddin, 2015, Pemetaan nilai rumput laut (seaweed value chain mapping) di Kabupaten Takalar, Maros, Pangkep dan Barru. Makassar

Surat Keputusan nomor 03/BMDs-GT/LB/KTB/II/2010 tentang pengelolaan hutan desa

Undang-Undang Nomor 6 Tahun 2014 tentang tentang Desa 